\title{
Management of the Energy and Economic Potential of Nuclear Waste Use
}

\author{
Bader Alshuraiaan ${ }^{1} \mathbb{D}$, Sergey Pushkin ${ }^{2} \mathbb{D}$, Anastasia Kurilova ${ }^{3}$ and Magdalena Mazur ${ }^{4, * \mathbb{D}}$ \\ 1 Department of Mechanical Engineering, Kuwait University, Safat 13060, Kuwait; alshuraiaan@yahoo.com \\ 2 Department of General Biology and Biodiversity, North Caucasus Federal University, \\ 355035 Stavropol, Russia; sergey-pushkin-st@yandex.ru \\ 3 Department of Masters Degree Programs (Business Programs), Togliatti State University, \\ 445020 Togliatty, Russia; aakurilova@yandex.ru \\ 4 Faculty of Management, Czestochowa University of Technology, 42-201 Częstochowa, Poland \\ * Correspondence: magdalena.mazur@pcz.pl
}

\begin{abstract}
Recently, issues related to the effects (benefit or harm) of processing nuclear waste and its further use as fuel have been increasingly often raised in the scientific discussion. In this regard, the research aims to investigate issues related to the assessment of the economic potential of nuclear waste use, as well as the cooperation between states in the context of the reduction of risks associated with nuclear waste storage and processing. The research methodology is based on an integrated approach, including statistical, factor analysis, and the proposed system of performance indicators for managing spent nuclear fuel use. The research was carried out on the basis of materials from Russia and the EU countries. In the course of the study, a model of cooperation between states has been developed (based on the example of technologies and methods of processing nuclear waste used in the EU and Russia) according to the nuclear waste (spent nuclear fuel) management algorithm. The model considers the risks and threats associated with ecology and safety. The developments and other results described in the study should be used in further research devoted to the use of nuclear waste as heat-producing elements.
\end{abstract}

Pushkin, S.; Kurilova, A.; Mazur, M Management of the Energy and Economic Potential of Nuclear Waste Use. Energies 2021, 14, 3709. https:// doi.org/10.3390/en14123709

Academic Editor:

Guglielmo Lomonaco

Received: 28 April 2021

Accepted: 18 June 2021

Published: 21 June 2021

Publisher's Note: MDPI stays neutral with regard to jurisdictional claims in published maps and institutional affiliations.

Copyright: (c) 2021 by the authors. Licensee MDPI, Basel, Switzerland. This article is an open access article distributed under the terms and conditions of the Creative Commons Attribution (CC BY) license (https:// creativecommons.org/licenses/by/ $4.0 /)$.

Keywords: economic security; nuclear power; nuclear waste processing; spent nuclear fuel; waste management

\section{Introduction}

The need to search for new sources of fuel and the disposal of hazardous nuclear waste are raising serious issues associated with the use of spent nuclear fuel. It should be noted that this issue has a dual economic nature. On the one hand, spent nuclear fuel is a rather dangerous type of energy waste requiring expensive disposal; on the other hand, it can be considered as a source of a number of important fuel elements and isotopes that can be used in heating processes [1,2].

Thus, at the moment, many developed and developing countries that have the potential for the development of nuclear energy are faced with a dilemma whether it is necessary to dispose of nuclear waste or to develop methods and technologies for its processing and further use [3,4].

Spent nuclear fuel is most often defined as heat-generating elements removed from the radiation zone, as well as groups of elements that nuclear power plant reactors and other installations are made of $[5,6]$.

The results of the theoretical analysis of terms and approaches to the definition of the concept indicate that spent nuclear fuel can be described as activities that may be associated with processing, reprocessing, transportation, storage, and disposal of fuel elements, in particular, reactive ones [7-10].

It should be noted that when considering the operation of power plants that rely on fossil fuels or alternative ("clean", renewable, including green) fuels, nuclear power plants 
(hereinafter referred to as NPPs) have fairly light carbon footprints. For example, according to nuclear energy research, when biomass is burned, on average, up to $230-240 \mathrm{~g}$ of $\mathrm{CO}_{2}$ per kWh can be released; for reference, when electric energy is generated by hydroelectric power plants (hereinafter referred to as HPPs), up to 23-25 g of $\mathrm{CO}_{2}$ per $\mathrm{kWh}$ is released while nuclear power plants produce only up to $10-12$ g of $\mathrm{CO}_{2} \mathrm{kWh}[11,12]$.

The burnup of fuel elements is determined by both nuclear and technological reasons, hence it can be quite different for different types of reactors. For the world's most popular LWR concept, this value ranges from 30,000 to 60,000 MWh/t HM. This implies that a typical LWR (with 1 GWe and an efficiency of about 33\%) will have a load of about 25/30 tons of WM per year at full power (FPY) and the same spent fuel discharge rate, of which the transuranic elements (TRU) constitute a substantial fraction. After about 3 years of continuous use inside the reactor core, the SNF is reloaded into cooling pools. This irradiation generates about 350 different nuclides (including 200 radioactive nuclides) with the following average composition: $94 \% \mathrm{U}^{238}, 1 \% \mathrm{U}^{235}$ (so spent nuclear fuel (SNF) continues to be enriched compared to $\mathrm{U}^{\text {nat }}$ ), $1 \% \mathrm{Pu}, 0.1 \% \mathrm{MA}, 34 \%$ fission products (FP). The decay of hazardous PDs reaches a few centuries, while Pu and MA have very long lifetimes, exceeding 100,000 years. Therefore, the management, reduction and safe disposal of SNF represent critical challenges to current and future nuclear power development [13].

There are a number of scientific theories confirming that spent nuclear fuel has significant energy and economic potential, which is the possibility of being reused [14-18]. In the future, it is expected to receive large amounts of energy with carbon content close to or equal to 0 . Globally, this will dramatically reduce greenhouse gas emissions [19-21].

However, at the same time, state authorities tend to give precedence (most often for political reasons) to nuclear power rather than renewable energy sources (in particular, solar, wind, water and other methods of energy generation). Among the key reasons are the fact that, firstly, spent nuclear fuel is a radioactive fuel element; secondly, on international communication platforms, there is a debate about the general position on the use of this type of energy; thirdly, spent fuel can be reused $[4,22,23]$.

There are various factors and reasons that force the government authorities of many countries to abandon spent nuclear fuel reprocessing. For example, in the United States, one of the key obstacles to the disposal of these substances is poor cost efficiency and the risk of using waste as a nuclear weapon. Back in the late 1970s, US President Jimmy Carter issued a decree banning nuclear fuel waste reprocessing and it was decided to store it deep underground. However, today there is an ecological problem associated with the danger of nuclear repository sites; the question is that there are few places (areas) that can be used to store nuclear waste. At the same time, some European countries (including France, Great Britain, Poland) and East Asian economies (for example, Japan) have different points of view on the issue. Thus, the governments of these countries tend to consider spent nuclear fuel as a valuable fuel asset rather than waste that needs to be disposed of [24].

When analyzing safety issues related to nuclear waste disposal, it should be noted that there have been 23 radiation accidents (since 1952) in the world's history related to nuclear power. Among them, accidents at nuclear reactors were the most severe (Three-Mile Island, Chernobyl (USSR), and Fukushima (Japan)). Accidents result in an urgent need for disposal, appropriate storage, and reprocessing of nuclear waste. At the same time, 13 incidents were recorded at reprocessing facilities, storage or disposal facilities [25]. Energy experts note that since the 1990s, nuclear reactors have been constructed in accordance with new international standards that are based on improved standardization and regulatory control [24,26]. In addition, nuclear electrical power is cheaper than other types.

It should be noted that the US corporate energy sector has been changing its point of view in recent years. For example, most reputable companies, such as General Electric, Pacific Gas \& Electric Co., and NRC, are developing methods for storing nuclear waste for its further processing with due regard to environmental risks and possible terrorist threats [27]. 
As for Russia, the country cooperates with Poland in the transportation and reprocessing of spent nuclear fuel. Thus, in accordance with an international agreement (USA, Russia, EU), concluded in 2009, and the Russian information sources, the An-124-100 cargo plane delivered highly enriched spent nuclear fuel from one of the Polish research reactors to Yekaterinburg (Russia). The fuel elements were delivered to the Mayak radiochemical plant for further processing [28].

However, at present, although spent nuclear fuel storage processes are well regulated at the national and international level, reprocessing processes are not recognized as completely safe. At the same time, there are no sustainable models of cooperation between states to manage these processes. This also affects the difficulties in assessing the economic potential of spent nuclear fuel use, which, in turn, determines the relevance of the research.

Thus, the purpose of the study is to determine how new nuclear waste processing technologies (REMIX and MOX technologies are considered in the framework of the study) based on cooperation between states with energy and economic potential in the field of nuclear power will help solve the problems associated with logistics and disposal of nuclear waste, as well as present spent nuclear fuel as a new competitive fuel element alongside traditional and renewable energy.

The study aims to:

- analyze the current use of nuclear waste (spent nuclear fuel) in the world;

- assess the situation in Russia and the EU countries (focus on Poland), as well as analyze the current and possible future cooperation between these countries;

- investigate the potential of nuclear waste (spent nuclear fuel) use for further processing to be used in heating processes;

- develop a model of cooperation between states (based on the example of nuclear waste processing technologies used in the EU and Russia) for the transportation, storage and processing of nuclear waste (spent nuclear fuel) with due regard to the risks associated with ecology and safety.

\section{Methods}

In accordance with the research purpose and objectives, the study examines two of the most effective and commonly implemented nuclear waste (spent nuclear fuel) reprocessing technologies, namely REMIX (Russia) and MOX (Western Europe).

Within the framework of the study, these technologies are considered in the context of comparing their economic and physical (technological) characteristics. Thus, mixed-oxide (MOX) fuel is considered as a type of fuel containing uranium dioxide and plutonium dioxide. Generally, based on the method, plutonium, which is separated from spent fuel in a chemical process, is mixed with uranium in its natural form, enriched or depleted, in accordance with the technology chosen. The Regenerated Mixture of U-PuOx (REMIX) technology fuel is considered as another type of independent fuel element (an alternative to MOX), which is obtained from the undivided mixture of regenerated uranium and plutonium, which is formed as a result of the use of pyrometallurgical spent nuclear fuel processing technology. When using this method, an electric current is required to form the combination of the elements; according to experts, this reduces the risks of plutonium proliferation $[11,28]$. In general, REMIX fuel can be viewed as a simplified version of MOX fuel. These technologies are discussed in more detail in the Results section.

The research consists of two major stages:

The first stage of the study is the assessment of the experience, the level of development of spent nuclear fuel reprocessing technologies in Russia and the EU countries based on the methods of economic and statistical analysis; the feasibility of application of these technologies, their advantages over the nuclear waste disposal and preference for reprocessed nuclear fuel as a fuel element has been evaluated.

Economic and financial analysis tools were used to study and compare the economic and technical characteristics of nuclear waste reprocessed based on these technologies in 
order to assess the potential of the use of spent nuclear fuel as a "new" fuel element in heating processes.

Next, based on the results and conclusions obtained in the framework of the first stage of the study, a model of cooperation between states with energy and economic potential in the field of nuclear energy was developed with the help of modeling, systematization, and structuring tools in order to organize logistics processes and reprocess nuclear waste (spent nuclear fuel) taking into account environmental and safety risks.

\section{Data Analysis}

At present, nuclear reactors mainly require enriched uranium-235. Natural uranium contains only $0.7 \%$ of uranium-235, of which $0.5 \%$ is used as the rest is lost during isotope separation and goes to waste. Natural uranium is mainly composed of uranium-238, which accounts for $99.3 \%$. In the traditional scheme, uranium-235 is fissioned to generate energy in reactors, and uranium-238 in its pure form is considered useless. The period of use of uranium-235 in a standard reactor is three years, then the reactor can be refueled even if it contains a lot of uranium-238. Spent fuel contains about $95 \%$ of its original energy when it is extracted by the nuclear power plant personnel. As a result, only $5 \%$ of its energy is used; in other words, about one tenth of uranium ore is converted into fuel and less than one hundredth of the total energy content is used to generate electricity. It should be noted that the current cost of uranium-235 extracted from natural uranium is 25 thousand dollars per $1 \mathrm{~kg}[12,29]$.

In 2019, the volume of uranium production in Russia was 2.9 thousand tons, while the consumption in the country is 6.5 thousand tons. The shortage is compensated by imports from the reserve fund created in the period of the USSR. The analysis of economic indicators of costs when using uranium-235 extracted from natural uranium confirms the feasibility of spent nuclear fuel use. The major component of spent nuclear fuel is uranium238. It accounts for about $94 \%$ of the total mass of uranium ore. Compared to other decay products, such as cesium-137 or strontium-90, it can be easily stored for future use in poorly protected facilities taking into account the separation from the rest of the material in the spent fuel. In addition, uranium-238 decays when hit by a fast neutron, i.e., when an atom of uranium-238 absorbs a neutron without splitting, it turns into plutonium-239, which, like uranium-235, supports a chain reaction and can be used to generate energy after reprocessing. The cost of reprocessing $1 \mathrm{~kg}$ of spent nuclear fuel ranges from $\$ 700$ to $\$ 2000$. A year of operation of the existing nuclear reactors results in up to 10,500 tons of spent nuclear fuel $[8,9,30]$.

Today, Rosatom is preparing to switch to a closed nuclear fuel cycle and to establish industrial production of regenerated mixture (REMIX) fuel. The innovative nuclear fuel is obtained from an undivided mixture of reprocessed uranium and plutonium, which is formed as a result of spent nuclear fuel processing, and a small amount of enriched uranium. According to experts, five REMIX fuel cycles are capable of meeting the needs of Russian NPPs for at least 60 years. Europe uses MOX-fuel (mixed oxides of plutonium and uranium), which involves reprocessing of spent nuclear fuel with accumulated plutonium as a result of irradiation of uranium-238. MOX fuel is widely used in nuclear power plants in Belgium, France, Germany and Switzerland. In Japan, twelve nuclear power plants are also licensed to use MOX fuel, and a MOX fuel fabrication facility is being licensed [31-34]. In the future, MOX fuel will be adapted for more modern reactors, such as PHWR and LMR. Table 1 shows a summary of the world's MOX fuel fabrication facilities.

MOX fuel is supposed to be used in Russian BN-800 and BN-1200 fast neuron reactors. For this purpose, the mining and chemical combine in Zheleznogorsk, commissioned in 2014, will produce up to 60 million tons of fuel for Russian nuclear power plants per year.

The UK, France, and Japan are also involved in nuclear waste reprocessing; their commercial processing capacity is 600,400 , and 800 tons per year, respectively. The nuclear waste market has been expanding in recent years. This is also facilitated by the growing demand for energy in developing countries and the trend towards nuclear energy 
generated from fossil fuels as a result of concerns about global warming. In addition, stricter regulation associated with the use of efficient fuels allows international nuclear waste companies to gain access to new markets. Figure 1 shows the dynamics of the global spent nuclear fuel market growth.

Table 1. Summary of MOX fuel fabrication facilities and capacities, 2018.

\begin{tabular}{|c|c|c|c|c|c|}
\hline \multirow[t]{2}{*}{ Country } & \multirow[t]{2}{*}{$\begin{array}{c}\text { Fuel } \\
\text { Fabricator }\end{array}$} & \multirow[t]{2}{*}{$\begin{array}{l}\text { Location of Fuel } \\
\text { Fabrication Facility }\end{array}$} & \multirow[t]{2}{*}{ Type of Fuel } & \multicolumn{2}{|c|}{ Production Capacity } \\
\hline & & & & Pellet & Assembly \\
\hline \multicolumn{6}{|l|}{ East Asia } \\
\hline Japan & $\begin{array}{l}\text { Japan } \\
\text { Nuclear } \\
\text { Fuel } \\
\text { Limited }\end{array}$ & Rokkasho-Mura & MOX (LWR) & 130 & 130 \\
\hline Asia Subtotal & & & & 130 & 130 \\
\hline \multicolumn{6}{|l|}{ Western Europe } \\
\hline France & AREVA & Marcoule & MOX (LWR) & 195 & 195 \\
\hline Europe Subtotal & & & & 195 & 195 \\
\hline \multicolumn{6}{|l|}{ Other } \\
\hline India & $\begin{array}{l}\text { Advanced } \\
\text { Fuel } \\
\text { Fabrication } \\
\text { Facility } \\
\text { (DAE) }\end{array}$ & Tarapur & $\begin{array}{l}\text { MOX (LWR, } \\
\text { PHWR) }\end{array}$ & 50 & 50 \\
\hline Russia & $\begin{array}{l}\text { TVEL, } \\
\text { Mining } \\
\text { \&amp; } \\
\text { Chemical } \\
\text { Complex } \\
\text { (MCC) }\end{array}$ & Zheleznogorsk & MOX (LMR) & 60 & 60 \\
\hline Other Subtotal & & & & 110 & 110 \\
\hline Total Installed N & Fuel Fabrication Ca & r World & & 435 & 435 \\
\hline
\end{tabular}

Source: developed by the authors based on data from [35].

The Polish government is also engaged in solving the problem of providing the country with electricity through the use of nuclear energy. PolskaGrupaEnergetycznaElektrowniaJdrowa (Kartoszyno, Poland), the company responsible for the Polish nuclear power project, in early 2016 confirmed that two potential sites had been selected for the first nuclear power plant, where further environmental testing would be carried out. Both sites are located in northern Poland, not far from the Baltic Sea. According to the IAEA, Poland has implemented all the recommendations and proposals of the Integrated Nuclear Infrastructure Review Mission (INIR). The representatives of the Polish Ministry of Energy reported that Poland is taking all necessary measures to ensure its nuclear power safety. The program meets the highest standards and international best practices [37].

It should be noted that the global industry and power economy are generally becoming more environmentally friendly and the storage of spent nuclear fuel is an outdated practice; today household and production waste is almost completely processed. The nuclear industry is also switching to the use of 'recyclable materials'. There is another motivationthe reserves of uranium-235 are limited and there is a need for the options of using uranium-238 and thorium-232. 


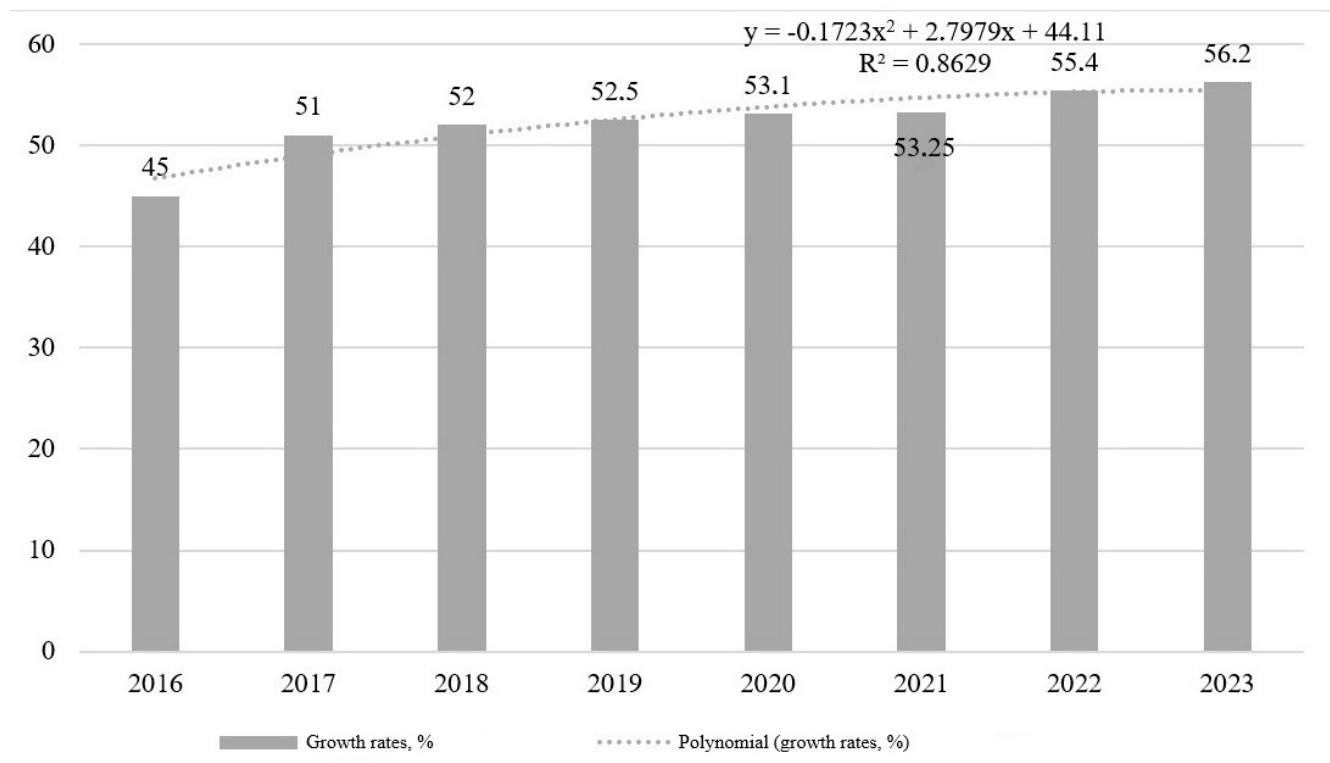

Figure 1. The growth rates of the global spent nuclear fuel market (taking into account forecasts for 2021-2023). Source: developed by the authors based on data from [36].

\section{Results}

Let us consider and analyze two major technologies for reprocessing spent nuclear fuel-MOX and REMIX-from the perspective of economic and technical characteristics.

Currently, it is MOX fuel that is reused in Europe. In addition, a number of European countries (Poland, France, Germany) often act as suppliers of MOX fuel or nuclear waste in the form of raw materials for other processing technologies (for example, cooperation between Poland and Russia).

In accordance with technical characteristics and properties, MOX fuel is most often used in fast-neutron reactors (for example, BN-600, BN-800, and BN-1200 that is under development, etc.). Reactors of these types can most efficiently use plutonium and make it from uranium $[11,34]$.

REMIX fuel (a Russian development) is still being tested and developed; however, according to the reports of Russian scientists, they will come up with an enhanced version of MOX fuel, which will be characterized by lower production cost, economic consumption, and greater environmental performance (impact on environment).

The study considered the technological features of nuclear fuel processing according to MOX and REMIX, which are shown in Figure 2.

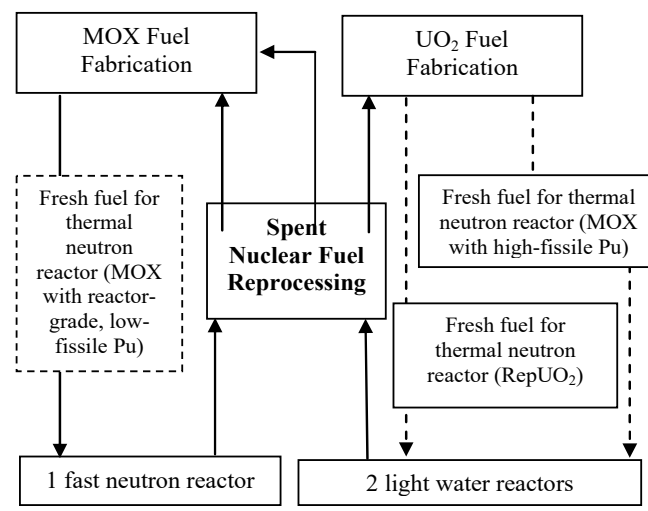

a)

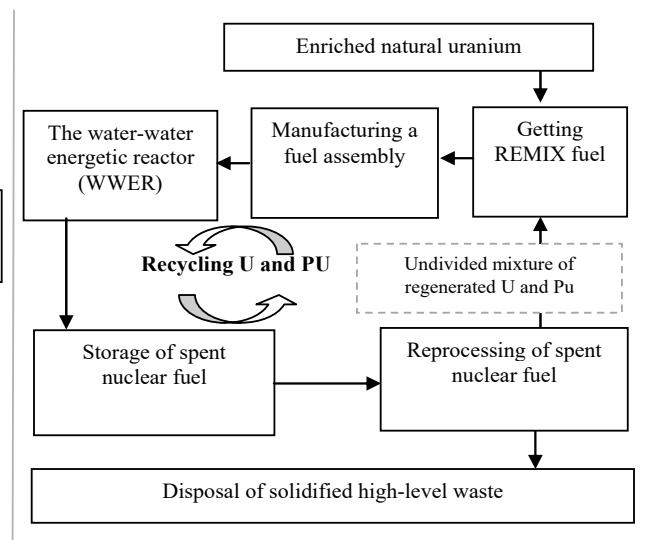

b)

Figure 2. Diagram of the MOX (a) and REMIX (b) processes. Source: Formed by the authors based on [38,39]. 
The main distinguishing feature of the technologies presented is that REMIX-fuel can be reprocessed repeatedly at $100 \%$ core fill in operating WWER and, therefore, can be used repeatedly up to five times, so that with less than three fuel loadings a reactor can operate for 60 years using this fuel. The use of REMIX fuel, like MOX fuel, reduces the consumption of natural uranium in WWER reactors by about $20 \%$ per recycle, as opposed to the open fuel cycle. REMIX can be used as a replacement for existing reactor fuels, but unlike MOX fuel, due to its high activity, the cost of fuel production is higher, with a cost increase of up to $25-30 \%$. If necessary, the REMIX cycle can be converted.

Table 2 shows the results of the comparison of the major economic and technical characteristics of REMIX (Russia) and MOX (EU) fuel.

Table 2. Comparison of the major economic and technical characteristics of REMIX (Russia) and MOX (EU) fuel.

\begin{tabular}{|c|c|c|c|}
\hline No. & Indicator & REMIX (Russia) & MOX (EU) \\
\hline 1 & Physical (technological) features & $\begin{array}{l}\text { A type of fuel that is obtained from the } \\
\text { undivided mixture of reprocessed uranium } \\
\text { and plutonium, which is formed as a result } \\
\text { of the use of pyrometallurgical spent } \\
\text { nuclear fuel processing technology. }\end{array}$ & $\begin{array}{l}\text { A type of fuel that contains uranium } \\
\text { dioxide and plutonium. Plutonium, which } \\
\text { is separated from spent fuel in a chemical } \\
\text { process, is mixed with uranium in its } \\
\text { natural, enriched or depleted form, in } \\
\text { accordance with the technology chosen. }\end{array}$ \\
\hline
\end{tabular}

(1) Increase in ecological efficiency through minimizing technogenic impact on the environment.

(2) Reduced cost of nuclear power plant operation and, as a consequence, reduction in the cost of electricity.

2 Main advantages

(3) Decrease in the accumulation of high-level waste

(4) Conservation of uranium resources.

(5) Significant reduction in the amount of final waste generated in the nuclear industry.

(6) One of the solutions to the problem of using highly radioactive plutonium in power industry.

3 Price $450-700 \$ / \mathrm{kg}^{*} \quad 297-937 \$ / \mathrm{kg}$ *

Natural uranium saving

4 compared to an open nuclear $\quad 20-30 \%$ compared to an OFC ${ }^{* *} \quad 15-25 \%$ compared to an OFC ** fuel cycle (OFC)

* Depending on the reactor type. ${ }^{* *}$ Errors may occur due to processing/production technologies. Source: Formed by the authors based on $[5,29,37]$.

As can be seen, the advantages of nuclear waste (spent nuclear fuel) reprocessing are characteristic of both MOX and REMIX fuel. The key difference between REMIX fuel and MOX fuel is the fact that in production, uranium and plutonium contained in the fuel produced using either technology are not separated. REMIX fuel does not have enough fissile nuclides, and therefore plutonium or enriched uranium is added.

The REMIX technology ensures a higher conservation rate of natural uranium compared to the open nuclear fuel cycle (OFC); however, given the wider distribution of MOX fuel in the world and the fact that REMIX is still at the development stage, more accurate results will be obtained later.

The price range varies due to the diversity of reactors producing the finished product; however, when compared with the generation of energy in the process of a more toxic open nuclear cycle, the price of fuel manufactured based on both technologies exceeds the cost of the OFC by $5-7$ times.

It should be noted that despite the current uncertainty, the assessment of the potential of the REMIX technology to use spent nuclear fuel is higher than that of the MOX technology. First of all, this is due to the fact that the volume of uranium production in Russia in 2017-2018 amounted to about 2.9-3.0 thousand tons while the level of consumption was 6.5-7 thousand tons, including the coverage of the deficit by imports and the reserve fund; thus, according to Russian estimates, thousands of tons of spent nuclear fuel accumulated over many years of the Russian nuclear industry operation and the use of a five-cycle fuel 
processing technology can meet the needs of both the Russian and world energy markets for many decades to come.

The advantages of closed fuel cycle technologies (MOX, REMIX) over the traditional open cycle fuel technology that is more toxic should also be mentioned. According to the methodology for calculation of recycles with REMIX fuel, the following parameters were calculated, which were further used to estimate natural uranium consumption: fuel consumption and enrichment, as well as consumption of uranium-plutonium regenerate. These parameters are shown in Table 3 and presented in tons per year (for 42 fuel assemblies).

Table 3. Change of material flows in the fuel cycle with REMIX in the process of multiple recycling, tons per year.

\begin{tabular}{lcccccc}
\hline \multicolumn{1}{c}{ Loading: } & & Recycle 1 & Recycle 2 & Recycle 3 & Recycle 4 & Recycle 5 \\
\hline Fuel enrichment & & 0.938 & 0.956 & 0.969 & 0.977 & 0.981 \\
& & $(61.1 \%)$ & $(57.4 \%)$ & $(55.1 \%)$ & $(54.0 \%)$ & $(53.6 \%)$ \\
\hline U-Pu & 17.06 & 16.95 & 16.92 & 15.88 & 16.89 & 16.88 \\
regenerate & 0.206 & 0.271 & 0.305 & 0.326 & 0.339 & 0.338 \\
U-Pu & 0.00 & 0.00 & 0.00 & 0.00 & 0.00 & 0.00 \\
regenerate to the warehouse & 0.00 & 0.00 & 0.00 & 0.00 & 0.00 & 0.00 \\
U-Pu & $\mathrm{U}$ & 16.96 & 16.92 & 16.87 & 0.89 & 16.85 \\
regenerate & $\mathrm{Pu}$ & 0.272 & 0.305 & 0.324 & 0.337 & 0.347 \\
Minor actinides and fission products & 0.0433 & 0.0432 & 0.0574 & 0.0658 & 0.0715 \\
\hline
\end{tabular}

Source: the authors' calculations.

Thus, based on the data given in Table 3, Figures 3 and 4 show the data on the consumption of natural uranium, separative work units, and natural uranium conservation in comparison with an open nuclear fuel cycle. It should be noted that in an open fuel cycle, spent nuclear fuel is considered to be highly radioactive waste, which is excluded from further use along with residual fissile isotopes and goes to storage or disposal facilities.

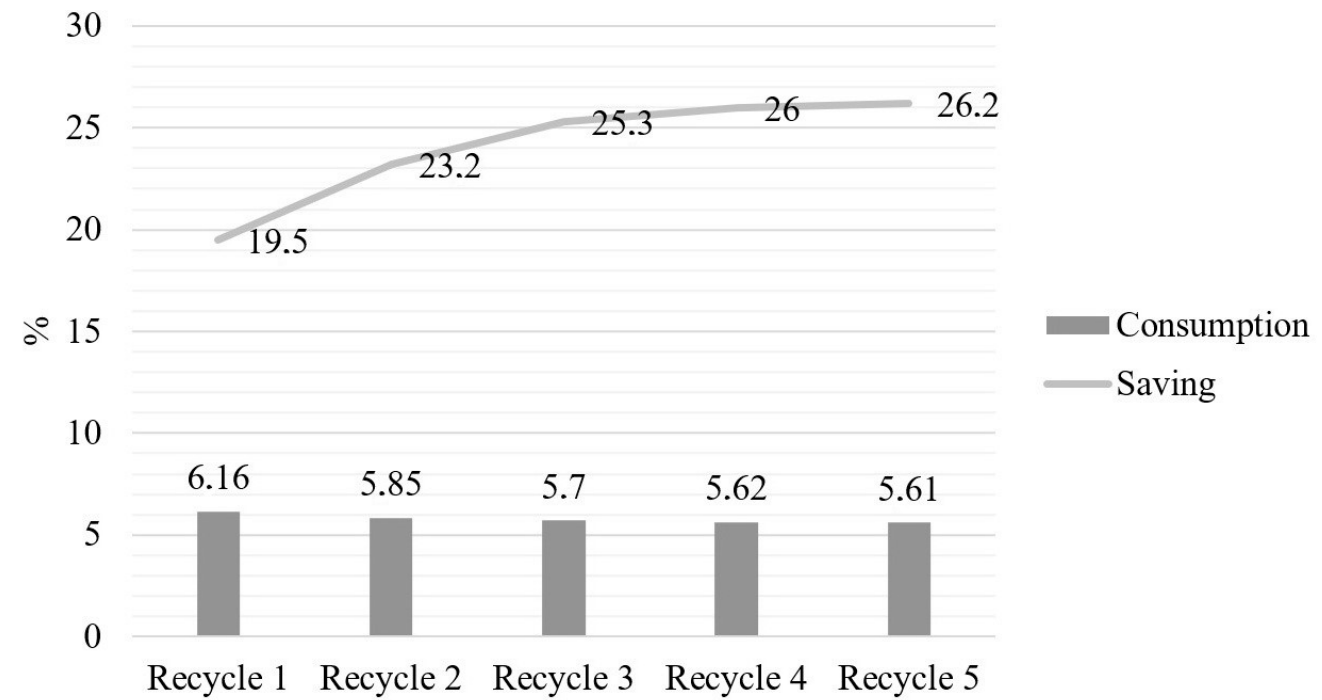

Figure 3. Indicators of consumption and saving (\%) of natural uranium when testing the REMIX method for a nuclear reactor of the WWER-1000 type in comparison with an open nuclear fuel cycle (waste $y=0.2 \%$ ). Source: own calculations. 


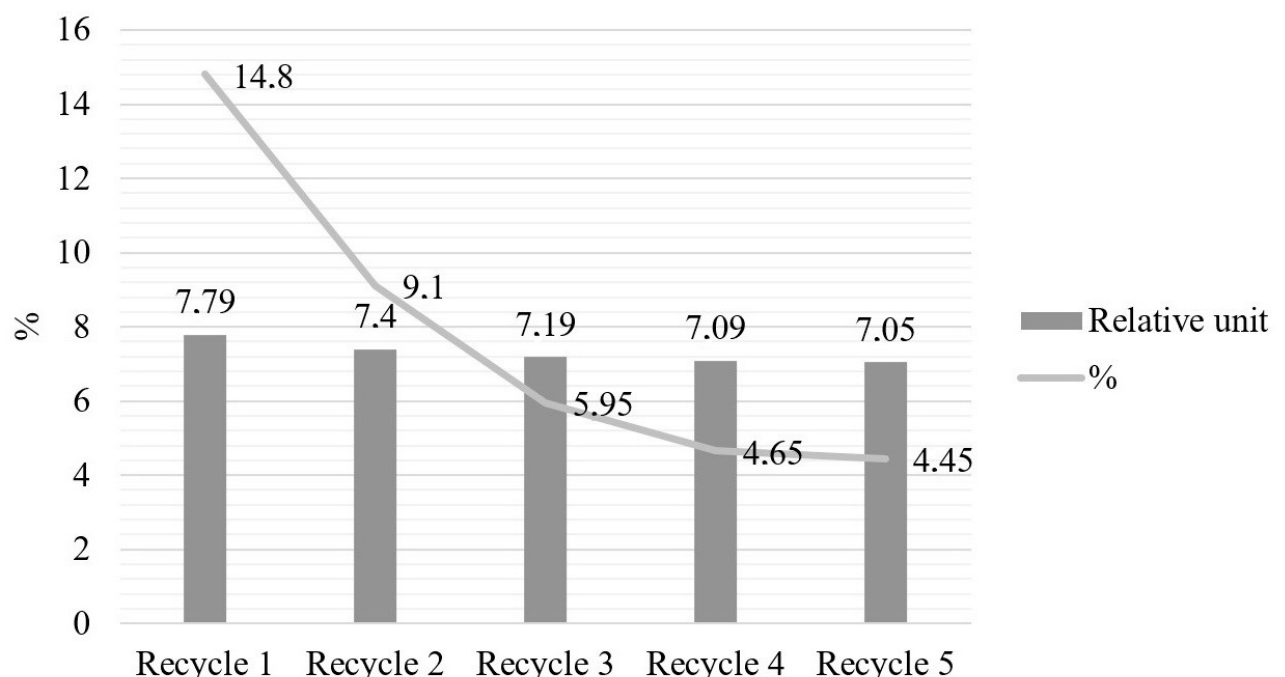

Figure 4. Change in the separative work unit when testing the REMIX method for a nuclear reactor of the WWER-1000 type of uranium fuel in comparison with an open nuclear fuel cycle (waste $y=0.2 \%$ ). Source: own calculations.

To assess the effect of reactor campaign duration on the efficiency of a closed nuclear fuel cycle with REMIX fuel, 5-recycle calculations were performed using the fresh fuel isotopic composition approach. The isotopic composition for the 1st recycle was formed on the basis of reprocessing of spent regular uranium fuel with the average burnup of the fuel assemblies unloaded during the one and a half year reactor campaign. The average burnup of the unloaded fuel assemblies was $49.4 \mathrm{MWd} / \mathrm{kgHM}$. The average enrichment for the standard WWER-1000 uranium load in this case was $\sim 4.75 \%$. The corresponding indicators for five cycles of nuclear waste use have been determined. Thus, it is possible to estimate the correlation between the amount of cost reduction and natural uranium savings. The results indicate reduced costs and increased savings of natural uranium, which confirms savings of $20-30 \%$ (Figure 4 ).

As can be seen, closed fuel cycle technologies are more cost-effective. The change in the separative work unit when testing the REMIX method also confirms the advantages noted above.

In general, according to the analysis method tested in the study, REMIX fuel can save natural uranium by $20-30 \%$ in comparison with the OFC. The results of the end-to-end nuclear fuel cycle analysis (based on the analysis of the MOX and REMIX methods) indicate that recently mixed schemes have been most commonly found in the internal and external energy markets of both developed and developing countries. Thus, for example, MOX fuel is characterized by the division of economies into states supplying raw materials, states dealing with processing and states supplying the finished product to the markets. At the same time, given the fact that REMIX fuel is still being developed, Russia acts as a producer and supplier of both raw materials and a finished product.

A model of cooperation between states describing the algorithm of nuclear waste (spent nuclear fuel) management is given below. Within the framework of the model, the key element is the risk regulators, which include methods and tools that will help states prevent major risks and threats associated with the operation and use of spent nuclear fuel and perform various functions in the process of preparation, processing and market distribution of reprocessed nuclear waste as an element that is reused in the energy sector (in particular, in heating processes) (Figure 5). 


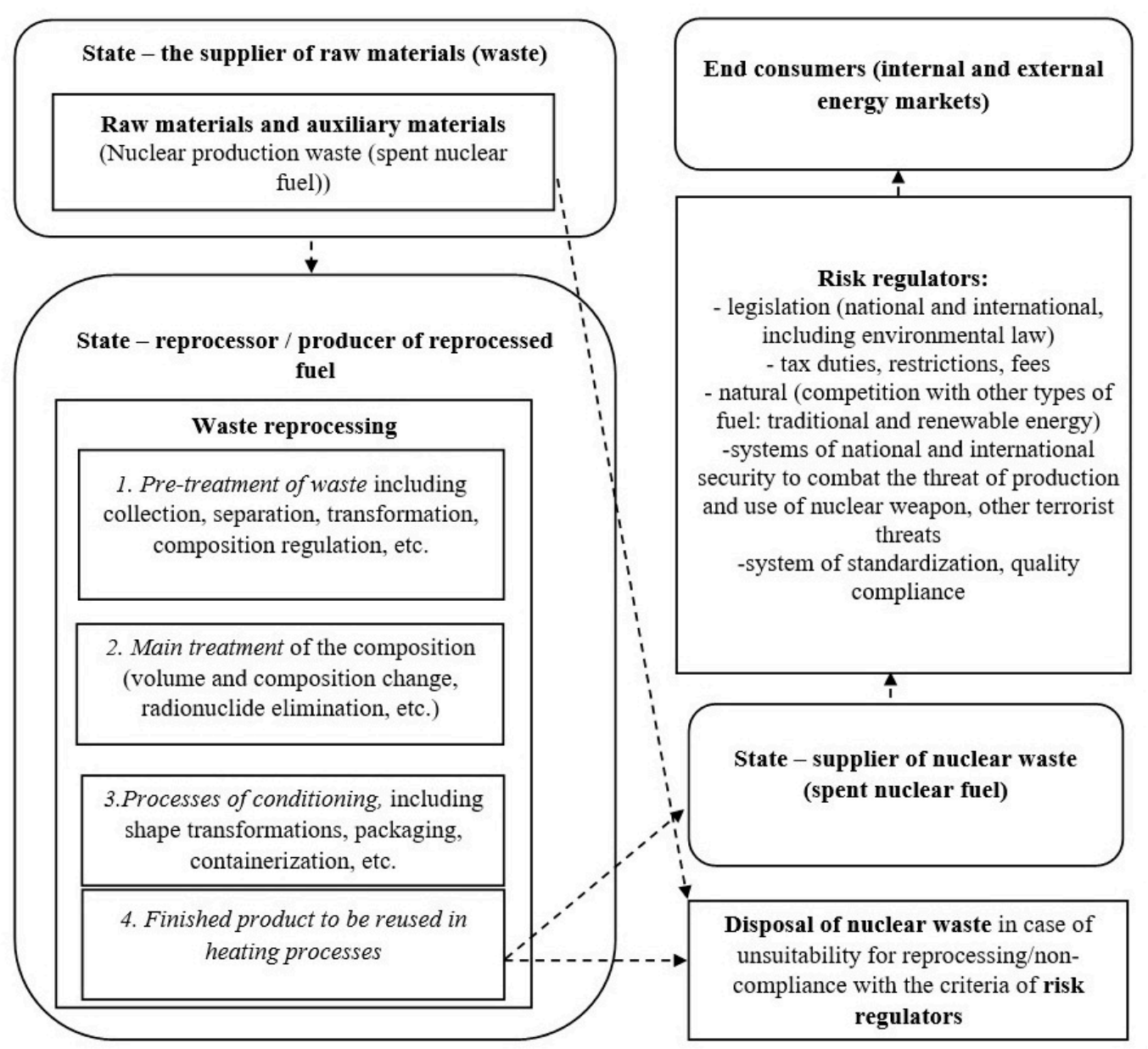

Figure 5. Model of cooperation between states describing the algorithm of nuclear waste (spent nuclear fuel) management. Source: own development.

\section{Discussion}

In the context of spent nuclear fuel management, studies, speeches and press releases of politicians, public figures, and forums of international organizations, are mainly associated with the analysis of the end-to-end nuclear fuel cycle and the feasibility of including an additional waste processing process in its structure for secondary use in heating processes. In addition, scientific community is increasingly focused on the study of the issues of disposal and transportation of spent nuclear fuel. It is often noted that despite the fact that a third of the spent fuel accumulated in the world is subject to reprocessing, its major part is stored until a decision is made on what to do with it-reprocess or dispose of it. It is determined by such factors as political strategies, technology development, stages of the nuclear fuel cycle, the choice of its final stage (reprocessing or disposal), etc. [40,41].

Another line of discourse concerns the safety of further use of nuclear waste. It should be noted that in the context of the production cycle safety, many experts agree that the hazards of the end-to-end nuclear fuel cycle can be reduced through careful observance of safety rules, labor protection, production regulations, etc. [27,28,42]. In particular, when working with spent nuclear fuel, it is important to take into account the factors of reliability, lean production, as well as to ensure proper storage of waste after removing it from the radiation zone for the purpose of further reprocessing or, in case of unsuitability, final disposal $[43,44]$. Safe, reliable, resilient, and cost-effective nuclear fuel cycles that can minimize hazardous waste generation and environmental impact contribute to the global sustainability of nuclear power $[45,46]$.

In scientific and practical (business format) discussions, the importance of cooperation between states in the context of the application of new best practices and the exchange of 
experience in the field of spent nuclear fuel management is highlighted [47,48]. Thus, an international legal framework should be developed. For example, the Joint Convention on the Safety of Spent Fuel and Radioactive Waste Management [21,24] contains both recommendations and mandatory requirements, in particular for the states that have signed this document. The main objectives are to improve the capacity to plan, develop and implement safe, environmentally friendly and effective strategies and technologies for the management of spent nuclear fuel. In addition, one of the major tasks of cooperation between states is the need to identify and solve technological problems related to the use of spent nuclear fuel, management flexibility, and the analysis of future scenarios $[32,49]$. It should be noted that these theses are in line with our study, which describes a model of cooperation between states in the context of spent nuclear fuel reprocessing and storage management.

One of the obstacles to cooperation between states in the context of spent nuclear fuel management may be fears of political leaders about the possibility of using nuclear waste to produce nuclear weapon [20]

In addition, there are no perfect technologies for the transportation and storage of nuclear waste to be further reprocessed. It is said that spent fuel storage systems may need to be serviced for longer periods of time, which stimulates research and the development of programs to manage the logistics of spent nuclear fuel [34,50].

As for the discussion about the advantages of REMIX and MOX fuel, which are also considered in the framework of our study, it should be noted that in Russia, the preference is given to REMIX-technologies while in Western countries, on the contrary, the MOX technology is mainly used. At the same time, other more sophisticated processing technologies are being developed in some countries in order to reuse fertile (minor actinides, such as neptunium, americium and curium) and / or long-lived radionuclides (such as cesium and strontium) to make the nuclear fuel cycle more sustainable and to reduce the amount and radiotoxicity of the final waste to be disposed of. These technologies can be used in reactors in the long term $[20,30]$.

\section{Conclusions}

The results obtained in the course of the study indicate that on a global scale industry and energy are gradually becoming more environmentally friendly, and emissions of toxic industrial waste into the atmosphere are decreasing. Within the framework of this paradigm, the approach to the storage (disposal) of nuclear fuel waste can be considered outdated. Both developed (for example, EU countries) and developing countries (Russia) are gradually switching to the use of nuclear fuel waste reprocessing models. In addition, there is another important motive- the depletion of uranium reserves in the world. A complete transition to renewable energy in the coming decades is not possible, and this issue is still somewhat controversial.

In western markets, spent nuclear fuel that has been reprocessed-MOX fuel-is used. At the same time, Russia is developing a more economical and environmentally friendly REMIX fuel. According to Russian scientists, the introduction of fuel processed with the help of this technology can bring significant effects. In particular, the study results allow concluding that reprocessing based on the REMIX technology with the possibility of multiple use of nuclear fuel will significantly reduce the amount of recovered uranium, plutonium waste, and natural uranium consumption by almost $20-30 \%$. The use of this technology provides a real opportunity and expediency to reduce the nuclear fuel cycle.

A closed fuel cycle technology (based on the example of the MOX and REMIX fuel) has significant advantages over the highly toxic and more hazardous open cycle from the point of view of production safety. This creates a strategic basis for the development of nuclear energy in the long term.

At the same time, it is important to develop a stable spent nuclear fuel management policy, which will solve the strategic tasks of the power industry and reduce current risks and threats. 
Thus, the research results make it clear that the potential of nuclear waste (spent nuclear fuel) use for further processing to be used in heating processes is significant, but it takes time to regulate energy markets taking into account the emergence of a new product-reprocessed nuclear fuel waste-and stabilize political issues in this regard.

An important result of the work is the development of a model of cooperation between states describing the algorithm of nuclear waste (spent nuclear fuel) management taking into account the risks and threats associated with the environment and safety. This study proves the real possibility and feasibility of closing the nuclear fuel cycle, which can be recommended for inclusion in the complex of a modern strategy for long-term energy security. The study confirms the importance of cooperation between states in the context of applying new best practices and experience exchange in nuclear waste management. The research results not only suggest a recommendation but an objective need to develop the international legal framework.

In general, it can be said that the developments and results described in the study are recommended for use in further research on the potential of the use of nuclear waste in energy processes and nuclear power industry. In the future, the study can assess the impact of energy and economic potential of nuclear waste management on the sustainable development of countries and regions. At the same time, it is advisable to develop methodological tools for assessing recycling activities' efficiency, as well as to form strategic initiatives at a state level that can contribute to solving global nuclear waste problems.

In the future, the study can be expanded to determine the impact of nuclear waste management on the sustainable development of countries and regions, and to increase the effectiveness of long-term energy security in a dual context. This implies further research towards both minimization of natural uranium consumption and scenario modeling of REMIX transition options and replacement of existing reactor fuels.

Author Contributions: Conceptualization, B.A., M.M. and A.K.; methodology, S.P.; software, B.A.; validation, B.A., S.P. and A.K.; formal analysis, A.K.; investigation, S.P.; resources, B.A.; data curation, A.K.; writing—original draft preparation, B.A.; writing-review and editing, M.M. and S.P.; visualization, B.A.; supervision, M.M. and S.P.; project administration, S.P.; funding acquisition, A.K. All authors have read and agreed to the published version of the manuscript.

Funding: This research received no external funding.

Institutional Review Board Statement: Not applicable.

Informed Consent Statement: Not applicable.

Data Availability Statement: Data will be available on request.

Conflicts of Interest: The authors declare no conflict of interest.

\section{References}

1. Alexander, W.R.; Mckinley, L.E. Deep Geological Disposal of Radioactive Waste; Elsevier: Amsterdam, The Netherlands, 2007.

2. Chapman, N.A. Who might be interested in a deep borehole disposal facility for their radioactive waste? Energies 2019, 12, 1542. [CrossRef]

3. Fuks, L.; Herdzik-Koniecko, I.; Kiegiel, K.; Zakrzewska-Koltuniewicz, G. Management of radioactive waste containing graphite: Overview of methods. Energies 2020, 13, 4638. [CrossRef]

4. Peakman, A.; Gregg, R. The fuel cycle implications of nuclear process heat. Energies 2020, 13, 6073. [CrossRef]

5. International Atomic Energy Agency. Enhancing Benefits of Nuclear Energy Technology Innovation through Cooperation among Countries: Final Report of the INPRO Collaborative Project SYNERGIES; IAEA Nuclear Energy Series, No.4; IAEA: Vienna, Austria, 2018.

6. International Atomic Energy Agency. International Conference on Management of Spent Fuel from Nuclear Power Reactors-An Integrated Approach to the Back End of the Fuel Cycle; IAEA: Vienna, Austria, 2015.

7. Gregory, R.; Kunreuther, H.; Easterling, D.; Richards, K. Incentives policies to site hazardous waste facilities. Risk Anal. 1991, 11, 667-675. [CrossRef]

8. Atomic Energy 2.0. Russia Fulfills Its International Obligations. Spent Nuclear Fuel Delivered to PA Mayak from the Republic of Poland. Available online: http:/ / www.atomic-energy.ru/news/2016/10/04/69406 (accessed on 8 December 2020).

9. Atomic Energy 2.0. Spent Nuclear Fuel (SNF). Available online: http:/ / www.atomic-energy.ru/snf/news?page=10 (accessed on 8 December 2020). 
10. Frano, R.L.; Pugliese, G.; Forasassi, G. Thermal analysis of a spent fuel cask in different transport conditions. Energy 2011, 36, 2285-2293. [CrossRef]

11. Bobrov, E.A. Research of Fuel Cycle Closure Characteristics for VVER Reactors Based on REMIX Technology. Ph.D. Thesis, Kurchatov Institute, Moscow, Russia, 2016.

12. International Atomic Energy Agency. Generic Post-Closure Safety Assessment for Disposal of Disused Sealed Radioactive Sources in Narrow Diameter Boreholes; IAEA-TECDOC-1824; IAEA: Vienna, Austria, 2017.

13. Bomboni, E.; Cerullo, N.; Lomonaco, G. Assessment of LWR-HTR-GCFR integrated cycle. Sci. Technol. Nucl. Install. 2009, $2009,193594$.

14. Wattal, P.K. Back end of Indian nuclear fuel cycle-A road to sustainability. Progr. Nucl. Energy 2017, 101, 133-145. [CrossRef]

15. Bourg, S.; Poinssot, C. Could spent nuclear fuel be considered as a non-conventional mine of critical raw materials? Progr. Nucl. Energy 2017, 94, 222-228. [CrossRef]

16. Gao, R.; Choi, S.; Ko, W.I.; Kim, S. Economic potential of fuel recycling options: A lifecycle cost analysis of future nuclear system transition in China. Energy Policy 2017, 101, 526-536. [CrossRef]

17. Kim, I.G.; Bang, I.C. Spent nuclear fuel with a hybrid heat pipe for electricity generation and thermal management. Energy Convers. Manag. 2018, 173, 233-243. [CrossRef]

18. Galamboš, M.; Rosskopfová, O.G.; Kufčáková, J.; Rajec, P. Utilization of Slovak bentonites in deposition of high-level radioactive waste and spent nuclear fuel. J. Radioanal. Nucl. Chem. 2011, 288, 765-777. [CrossRef]

19. Artak, B.; Gagik, M. Transportation and Storage of Spent Nuclear Fuel: Security and Theory. In Transport of Dangerous Goods; Springer: Dordrecht, The Netherlands, 2011; Volume 1, pp. 227-249.

20. Biello, D. Spent Nuclear Fuel: A Trash Heap Deadly for 250,000 Years or a Renewable Energy Source? Scientific American, 28 January 2009. Available online: https:/ / www.scientificamerican.com/article/nuclear-waste-lethal-trash-or-renewable-energy-source/ (accessed on 8 December 2020).

21. Timofeev, A.V. On the theory of plasma processing of spent nuclear fuel. Instruments and methods of investigation. Phys. Sci. Achiev. Russ. Acad. Sci. Phys.-Uspekhi 2014, 57, 10.

22. Laughton, M.A.; Warne, D.J. Electrical Engineer's Reference Book, 16th ed.; Elsevier: Amsterdam, The Netherlands, 2003.

23. Newman, A.; Nagtzaam, G. Decision-Making and Radioactive Waste Disposal; Routledge: Abingdon, UK, 2016.

24. Hightech. The Second Life of Uranus: What Is Being Done in the Modern World with Spent Nuclear Fuel. Available online: http: / / www.hightech.fm/2019/10/21/nuclear-second (accessed on 8 December 2020).

25. United Nations Scientific Committee on the Effects of Atomic Radiation. Sources and Effects of Ionizing Radiation-2008 Report to the General Assembly. Available online: http://www.unscear.org/docs/reports/2008/11-80076_Report_2008_Annex_C.pdf (accessed on 2 June 2021).

26. Setzman, E. Preparing for implementation, construction and public support: The Added Value Programme. In Proceedings of the Annual Waste Management Symposium (WM2014), Phoenix, AZ, USA, 2-6 March 2014; Curran Associates: Red Hook, NY, USA, 2014; p. 357.

27. Leo, D.W.; Warhoe, S. Third party cold-eyed estimate reviews and validation. In Cost Engineers' Notebook, 2nd ed.; Stephenson, H.L., Ed.; AACE International: Morgantown, WV, USA, 2016.

28. Kharitonov, V.V. Dynamics of Nuclear Power Development. Economic and Analytical Models; MEPhI Publ.: Moscow, Russia, 2014.

29. International Atomic Energy Agency. Energy, Electricity and Nuclear Power Estimates for the Period up to 2050; Reference Data Series No. 1; IAEA: Vienna, Austria, 2017.

30. International Atomic Energy Agency. Spent Fuel Management. Available online: http://www.iaea.org/topics/spent-fuelmanagement (accessed on 8 December 2020).

31. World Nuclear Association. The Nuclear Fuel Report. Global Scenarios for Demand and Supply Availability 2017; World Nuclear Association: London, UK, 2017.

32. Tsai, T.-L.; Chiou, Y.-F.; Tsai, S.-C. Overview of the nuclear fuel cycle strategies and the spent nuclear fuel management technologies in Taiwan. Energies 2020, 13, 2996. [CrossRef]

33. Organisation for Economic Co-operation and Development. Uranium 2018: Resources, Production and Demand. OECD 2018, NEA No. 7413. Nuclear Energy Agency, Organisation for Economic Cooperation and Development; OECD: Paris, France, 2018.

34. International Atomic Energy Agency. World Distribution of Uranium Deposits (UDEPO), 2016th ed.; IAEA: Vienna, Austria, 2018.

35. ScienceDirect Topics. Mixed Oxide Fuels_An Overview. Available online: https://www.sciencedirect.com/topics/engineering/ mixed-oxide-fuels (accessed on 8 December 2020).

36. Africa Nuclear Business Platform. Nuclear Waste Management Overview \& Opportunities. Available online: http://www. nuclearbusiness-platform.com/africa/industry-insights/nuclear-waste-management-overview-opportunities-2/ (accessed on 8 December 2020).

37. European Commission. EURATOM Supply Agency ANNUAL REPORT 2016. Available online: https:/ / ec.europa.eu/euratom/ ar/ar2016.pdf (accessed on 8 December 2020).

38. Atomic Energy 2.0. Reprocessing Irradiated Fuel: New Requirements and Innovative Approaches. Available online: https: / / www.atomic-energy.ru/articles/2012/04/26/33029 (accessed on 2 June 2021).

39. World Nuclear Association. Mixed Oxide (MOX) Fuel. Available online: https://world-nuclear.org/information-library/nuclearfuel-cycle/fuel-recycling/mixed-oxide-fuel-mox.aspx (accessed on 2 June 2021). 
40. Andersen, B.; Samset, K.; Welde, M. Low estimates-High stakes: Underestimation of costs at the front-end of projects. Int. J. Manag. Proj. Bus. 2016, 9, 171-193. [CrossRef]

41. Devos, L. AREVA Sustainable Back-End Solutions for Smooth and Optimized Nuclear Development. Available online: http: //2019.atomexpo.ru/2015/mediafiles/u/files/materials /6/Devos.pdf (accessed on 8 December 2020).

42. Klyuchnikov, A.A.; Pazukhin, E.M.; Shiger, Y.M.; Shiger, V.Y. Nuclear Power Plant Radioactive Waste and Methods of Handling Them; IPB NPP NAS of Ukraine: Kyiv Oblast, Ukraine, 2005.

43. Joshi, S.; Bhargava, P. Waste management integration with Green Quality Function Deployment (G-QFD) for Healthcare Centre. Prod. Eng. Arch. 2019, 22, 45-49. [CrossRef]

44. Bednarova, L.; Džuková, J.; Grosoš, R.; Gomory, M.; Petráš, M. Legislative instruments and their use in the management of raw materials in the Slovak Republic. Acta Montan. Slovaca 2020, 25, 105-115.

45. Swissnuclear. Swissnuclear, Kostenstudie 2016 (KS16), Schätzung der Entsorgungskosten: GeologischeTiefenlagerung, SwissnuclearBericht FGK-AN-16.043; Swissnuclear: Olten, Switzerland, 2016.

46. International Atomic Energy Agency. Technological and Organizational Aspects of Radioactive Waste Management; IAEA Training Course Series; IAEA: Vienna, Austria, 2005.

47. Andrzejewski, M.; Dunal, P.; Popławski, Ł. Impact of changes in coal prices and $\mathrm{CO}_{2}$ allowances on power prices in selected European Union countries-correlation analysis in the short-term perspective. Acta Montan. Slovaca 2019, $24,53-62$.

48. Philbin, S.P.; Kennedy, D. Exploring the need for a new paradigm in engineering management and the decision-making process in technology-based organisations. Eng. Manag. Prod. Serv. 2020, 12, 7-21.

49. Uliyanin, Y.A.; Kharitonov, V.V.; Yurshina, D.Y. Prospects for nuclear power in the context of the exhaustion of traditional energy resources. Univ. News Nucl. Energy 2017, 4, 5-16.

50. VanLuik, A. Ethical Considerations for Developing Repository Warning Messages to the Future; WM Symposia, Inc.: Carlsbad, NM, USA, 2016. 